\title{
Top soil layer equi-electrical conductivity and pollution with salts mapping for a region located within Baghdad city
}

\author{
Wadhah M. Shakir* Wea'am H. Kadim* \\ Mohammed A. Hazz'a* \\ Received 22, February, 2010 \\ Accepted 14, June, 2010
}

\begin{abstract}
:
This research deals with the study of top soil electrical conductive regions located within Baghdad City. The research included measuring the dissolved soil material extraction Electrical Conductivity (EC) with an aqueous solution for the top $(0-30 \mathrm{~cm})$ soil layer of the study area. As the electrical conductivity values increase by increasing the amount of dissolved salts in principle, we can consider that the aim of this research is to predict the amount and distribution of (soil contamination with salts) which is represented by the (Salt Index), this factor calculated for each soil representative sample taken from the region with a depth of $(30 \mathrm{~cm})$. Laboratory $(\mathrm{EC})$ test values measured by the use of solutions (EC) digital meter for the extract of the dissolved soils with a distilled de-ionized water using the ratio of $(2: 1)$.The distributed (EC) values for the field representative soil samples used lately to plot a contour equi-electrical conductivity map and EC soil fluctuation profiles, in which reflected the top soil layer salinity distribution according to Tigris river position in the study area, also it reflects the increase and decrease of this layer salinity in a relation to the river position. This study concluded that the highest soil salinity concentrations located at the southern east part of the study area, while the lowest concentrations are located on the intersection areas with Tigris river stream, other areas in which are few kilometers far from the river stream showed moderate salinity concentrations. These results could be helpful for Environmental and agricultural benefits, through identifying the salty soil pollution region and look for ways of treatment.
\end{abstract}

Key words: Electrical Conductivity, Soil EC, Soil extraction EC.

\section{Introduction:}

Measurements of the electrical conductivity or resistivity have been applied for soil salinity surveys for many years. [1]

Some geophysical methods are applied on soil surface like electrical profiling using a four electrode method like Wenner configuration as well as in bore-hole logging. [2]

Despite the previous promising geophysical methods of four electrode electrical profiling, electromagnetic induction method and GPR Ground Penetrating Radar it have some drawbacks. [3] This appears when used for shallow soil profiles, because of its disability of giving a direct measurement for different resistivities and conductivities of soil horizons. [4] And it provides only an average or bulk reading of electrical conductivity of the soil profile. [5]

The GPR method application is also limited on the evaluation of high conductivity soil profiles differentiation, like (salty soils, clay soils). [6] The GPR is not easily

*University of Baghdad/College of Science for Women /Dept. of Physics 
modified for shallow subsurface measurements. [7]

The relationship between electrical properties and other soil chemical and physical properties are very complex because many soil properties may simultaneously influence in the measured electrical parameters [8]

The equipments for geophysical methods of vertical electrical sounding , four electrode profiling, ground penetrating radar, etc. manufactured and readily available are not suitable for measuring electrical properties in shallow $(0-5 \mathrm{~m})$ soil profiles. $[9,10]$

According to the previous concepts, the Soil Extraction Electrical Conductivity for a fresh soil samples taken from the study area was the most satisfactory laboratory method to give the direct readings of electrical conductivity. [11]

Electrical conductivity (EC) is a measurement of the dissolved material in an aqueous solution, which relates to the ability of the material to conduct electrical current through it.[12]

Soil Electrical Conductivity (EC) is just one of many measurements producers can make of their fields to help them prepare for site-specific crop management. But, it may be one of the most meaningful. Mapping EC is generally considered a one-time procedure for a given field. On a per acre basis, it is one of the least expensive soil measurements. [13] A map of a field's electrical conductivity can provide considerable insight into how the soil profile varies in the field. Topsoil depth can change independent of the visible landscape. The influence of glacial deposition and the sequence of alluvial deposition, erosion, or loess deposits cause the main variations. Thus, we cannot accurately predict the properties of a soil profile by looking at the surface. [14]

The purpose of Soil EC study is to assist with the management of naturally-occurring salts in soils found in the landscape and in plant able areas. [15] Then the salts from irrigation water can also be concentrated due to drying of the media during evapotranspiration. [16]

A small amount of excess irrigation water should be provided to allow leaching from the container (usually about $20 \%$ of the water added). This leaching will ensure that salts do not accumulate and adversely affect the plants. Alternately, over-irrigation will lead to unnecessary leaching of plant nutrients. The electrical conductivity of the water should be measured regularly. If elevated readings are found, usually greater than 1.5 to 2.0 deciSiemens per meter ( $m$ mho per $\mathrm{cm}$ ), then the water should be mixed with better quality water before it is used for irrigation. If mixing is not possible, then this water should not be used for irrigation except by experienced water managers. Salt effects on plants increases during drying conditions. During drying, water is removed from the soil by evaporation from the soil surface and by transpiration from plants. Salts are left behind that were previously dissolved in the soil water, concentrating them and increasing the adverse impact on plants. Before using a water source for landscape or crop irrigation, the water should be tested for electrical conductivity (EC). Water with EC greater than 2.0 deciSiemens per meter $(2.0$ millimhos per centimeter) generally should not be used for irrigation. [15, 17]

The mechanism causing the salt accumulation in irrigated soils is evapotranspiration. The salt contained in the irrigation water is left behind in the soil as the pure water passes back to the atmosphere through the process of evaporation and plant transpiration. [18] 
The effects of salinity are manifested in loss of stand, reduced rates of plant growth, reduced yields, and in severe cases , total crop failure . [19]

\section{Geology and its effect on top soil layer:}

According to the geological previous studies, Baghdad province is located in the rocks outcrop zone that belongs to Pleistocene in addition to the recent alluvial sedimentary cover .Baghdad generally located within the plane unfolded zone according to the physiographic classification of reference [20] the unfolded zone includes the western desert and the fluvial plane, this zone extends to cover larger parts of Iraq including southern and western south regions. It is observed that a lateral thickness variation of sedimentary rocks take place toward south and south-west regions, this is due to the tectonic motions of faulting blocks that took place during Miocene.[20]

Once sediment forms, it can either be carried elsewhere and become buried by other sediment and transform into sedimentary rock or evolve in place at the earth's surface and change into soil. The soil consist of sediment that has undergone changes at the surface of the earth, including reaction with rain water and the incorporation of organic material, so that it can support the growth of plant life. There are three processes taking place below surface for soil formation which are:

1- Animals, plants and other organism's interaction with sediments.

2- The rain of surface water enters sediment and percolate downward in a region called zone of leaching this water dissolves ions and picks up very fine clay as water moves downward, it carries the ions and clay with it to a deeper zone called the zone of accumulation where a new minerals precipitate out of the water and the water leaves behind it load of fine clay.

3- Borrowing organisms like ants, worms ...etc. churn the soil ,so its fabric becomes different from that of the original sediment, and organic material from the ground surface get mixed in.[21]

\section{Materials and Methods:}

\section{Soil Sampling}

A soil samples taken from poorly planted and non-planted areas around city buildings and streets with a random pattern on both sides of Tigris river side's within the study area (Map.1), samples picking represented the depths of $(30 \mathrm{~cm})$ top soil to study the electrical conductivity that reflects contamination with salts, studying salinity with this depth is very important for agricultural benefits.

The soil samples kept within firm closed nylon bags in order not to lose humidity content, and then taken to the laboratory. The laboratory procedures could be simplified with the following steps:

- Weighing soil samples before and after drying using a digital balance.

- Preparing the soil solution by mixing $200 \mathrm{ml}$ of de-ionized distilled water with $100 \mathrm{mg}$ of dry soil.

- The extraction of soil solution.

- Measuring electrical conductivity for the soil extraction solution.

Soil extraction solution electrical conductivity measurement

A high performance digital electrical conductivity (EC) meter for solutions used to work out soil extraction solutions EC measurements in Laboratory, (Fig. 1), the resolution of the device was $0.01 \mathrm{u}$ mho to lowest range , and accuracy of $\pm 0.5 \% \mathrm{FSD} \pm 1$ digit, with operation temperature range of $10-50{ }^{\circ} \mathrm{C}$. [Device manufacturer manual] 


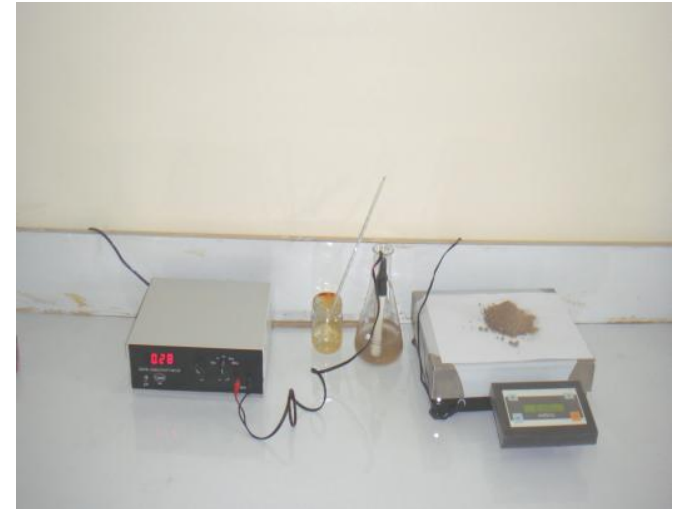

Fig.1 Shows the EC digital measurement device and the digital balance used in laboratory soil extraction EC test.

The device accessories were: Electrical conductivity digital meter, conductivity sensitive cell and a standard solution of $0.1 \mathrm{~N} \mathrm{KCL}$.

The device must be calibrated before taking EC measurements of soil extract solution; this had been done by the following steps:

1- Washing the measurement cell tip with distilled water.

2- Inserting the cell in the $0.1 \mathrm{~N} \mathrm{KCL}$ Calibration Solution, while an ordinary mercury thermometer used to measure the previous solution temperature.

3- Selecting the range switch at $10 \mathrm{~m}$ mho range, and setting the display calibration knob to read EC of calibration solution using the device (EC to Temperature) calibration chart, (prepared by the device manufacturer).

4- The temperature of the soil extract solution must be equal to the temperature of calibration solution. Washing the EC measurement cell tip with distilled water every time before inserting to each Soil Extract solution flask is very important to give a precise EC readings.

The EC readings are in ( $\mathrm{m}$ mho per $\mathrm{cm}$ ) in which is equal to (desiSeimens per m). [11]
The Calibration procedures vary by instrument, so following the manufacturer's instructions is highly recommended. It's important to be sure to rinse the measurement cell thoroughly before and after calibration using de-ionized water. EC meters should be calibrated before each use (before each series of samples, not between each sample itself) or when measuring a large range of $\mathrm{EC}, \mathrm{EC}$ measurement done by inserting the cell into the soil extraction sample and wait until the EC reading on the meter stabilizes. Many meters have automatic temperature correction (ATC), which calculates the EC taking into account temperature, if the meter does not have this feature, it might need to adjust the knob on the meter to correct the EC for temperature, then Recording the measurement when the EC reading is stable. [11, 21]

The University of Florida Extension Soil Testing Laboratories (ESTL) determined EC using a 2:1 solution: soil extraction. This procedure is more time-efficient, results in enough filtered solution for additional tests, and requires less skill to perform accurately. The saturated extract technique on Florida's sandy soils is much more difficult, especially at county laboratory facilities. Standardization among technicians is the biggest problem. For that reason, ESTL continues to use the $2: 1$ solution: soil extraction procedure. $[11,22]$

The ESTL reported soluble salt values for Florida soils in terms of parts per million (ppm), using a drysoil basis. This approach works poorly in much of the world, but it served Florida agriculture well, because of the uniformly sandy nature of Florida's mineral surface soils. However, because of its infrequent use elsewhere, the ppm dry-soil convention isolated Florida's growers and 
agricultural industry personnel from the large and steadily growing body of salinity literature world-wide. For this reason, the ESTL has been reporting only EC values (2:1) since 1989. [15]

The Estimation of a saturated extract EC, termed "Salt Index" in the following tables, from the 2:1 extract can be calculated using the following formula:

$$
\mathrm{EC}(\text { salt index })=\mathrm{EC}(2: 1) \times 8 .
$$

For example, a 0.2 deciSiemens per meter value from the $2: 1$ procedure is equivalent to a salt index of 1.6 deciSiemens per meter $(0.2 \times 8=1.6)$. The calculation is completed on the ESTL report form under the column "Estimated Salt Index." [15, 22, 23]

A tables prepared to include salt indexes and plants and crops that suits it for agricultural benefits and put the following simple procedures: [1]

1. Measure the EC of a 2:1 extract, beginning with air-dry soil.

2. Convert the $2: 1$ reading to a salt index (multiply by 8 ).

3. Use Tables to determine if the measured salt index that will affect selected crop.

\section{Results and Discussion:}

The same previous mentioned laboratory procedures had been applied on Baghdad city soil samples to measure the EC and salt index for every sample for every spot within the location of the study area as shown in (Fig.2) and (Table.1).
Table 1. Showing the EC and Salt index values gained from laboratory soil extraction solution EC test for the study area samples according to sample picking location.

\begin{tabular}{|c|c|c|c|}
\hline $\begin{array}{c}\text { Sample } \\
\text { No. }\end{array}$ & Location & $\begin{array}{c}\text { Measured } \\
\text { EC in } \\
\mathrm{m} \text { mho per } \\
\text { cm }\end{array}$ & $\begin{array}{c}\text { Salt index } \\
\text { value } d S / m\end{array}$ \\
\hline 1 & AL-Jamia'a Dist. & 1.34 & 10.72 \\
\hline 2 & AL- Harthiyah & 0.8 & 6.4 \\
\hline 3 & AL-Ma'amun Dist & 2 & 16 \\
\hline 4 & Southern Dawra & 2.8 & 22.4 \\
\hline 5 & $\begin{array}{c}\text { Jadriyah/U.O.Baghdad } \\
\text {,A }\end{array}$ & 0.35 & 2.8 (lowest) \\
\hline 6 & $\begin{array}{c}\text { Dawra /Refinary street } \\
\text {,west }\end{array}$ & 1.04 & 8.32 \\
\hline 7 & AL-Muwasalat Dist. & 0.58 & 4.64 \\
\hline 8 & $\begin{array}{c}\text { Dawra/Refinary } \\
\text { Street,East } \\
\end{array}$ & 6.40 & $\begin{array}{c}51.2 \\
\text { (highest) }\end{array}$ \\
\hline 9 & Karrada/AL-Ziwiyah & 0.78 & 6.24 \\
\hline 10 & $\begin{array}{c}\text { Jadriyah/ U.O.Baghdad } \\
\text {,B }\end{array}$ & 1.50 & 12 \\
\hline 11 & $\begin{array}{c}\text { Jadriyah/ U.O.Baghdad } \\
\text {,C }\end{array}$ & 1.73 & 13.84 \\
\hline 12 & Kadhimiyah & 0.65 & 5.2 \\
\hline 13 & AL-Hurriyah & 1.5 & 12 \\
\hline 14 & AL-Maghrib Street & 0.95 & 7.6 \\
\hline 15 & $\begin{array}{l}\text { Bayruit Square/Phalistine } \\
\text { St. }\end{array}$ & 1.8 & 14.4 \\
\hline 16 & AL-Nidhal St. & 1.7 & 13.6 \\
\hline 17 & Washash & 1.65 & 13.2 \\
\hline 18 & $\begin{array}{l}\text { Oman Square/ Karkh } \\
\text { side }\end{array}$ & 2.2 & 17.6 \\
\hline 19 & AL-Khadhra'a Dist. & 1.8 & 14.4 \\
\hline 20 & AL-Ma'arifah Dist. & 1.63 & 13.04 \\
\hline 21 & AL-Ummal Dist. & 1.5 & 12 \\
\hline 22 & AL-Tahariyat Square & 1.3 & 10.4 \\
\hline 23 & AL-Muradiyah & 3.2 & 25.6 \\
\hline 24 & $\begin{array}{l}\text { AL-Mustansriyah } \\
\text { Phalistine St. }\end{array}$ & 2.5 & 20 \\
\hline
\end{tabular}

The soil extraction samples EC readings projected on the map of Baghdad with the scale of 1:400 000, the EC readings used to draw an equiEC contour map showing the variation of EC in the study area (Fig.3, Fig.6). A manual equi-EC contour map (Fig.3) plotted and another one plotted using the Surfer 6.0 software program (Fig.6) and there is a good agreement in results between them.

A profile along the traverse $\mathrm{X}-\mathrm{Y}$ plotted to show EC fluctuation along the distance $\mathrm{X}-\mathrm{Y}$ as its shown in (Fig.3) and (Fig.4, Fig.8).

According to the results that shown on the (Fig.3, Fig.6) and the (Fig.4, Fig.7,Fig.8) we can conclude the following points: 
1- According to the equi-EC (Fig.3 and Fig.6), the lowest EC readings concentrated in the regions near Tigris river stream specially for the samples taken from Jadriyah island in which is surrounded with the river stream these samples represent the EC readings of $(0.35$, $0.78,1.73 \mathrm{~m}$ mho per $\mathrm{cm}$ ), another low EC readings observed near Washash in which is located to the north of the previous area and its near the Tigris river stream .

2- The regions of high EC readings represented by the area near Dawrah districts that recorded (6.4 $\mathrm{m}$ mho per $\mathrm{cm}$ ) EC reading in maximum ,these readings shown in (Fig.3) , (Fig.6) EC contour enclosures that located on the southern east part of the study area . by inquiry about this high levels of salinity it appeared that this area had been irrigated with non-EC tested saline water from 2 years ago, planting in this area failed for 3 times when different types of crops planted in it due to high salinity .

3- A moderate EC readings of (1-2 m mho per $\mathrm{cm}$ ) recorded on the few kilometers far from Tigris river stream on the Middle East and west parts of the study area.

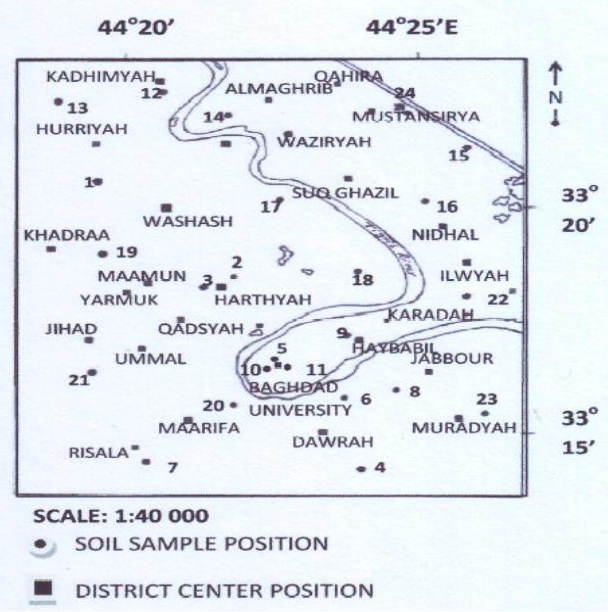

Fig.2: A manual Drawn map showing the study area location and soil samples position.

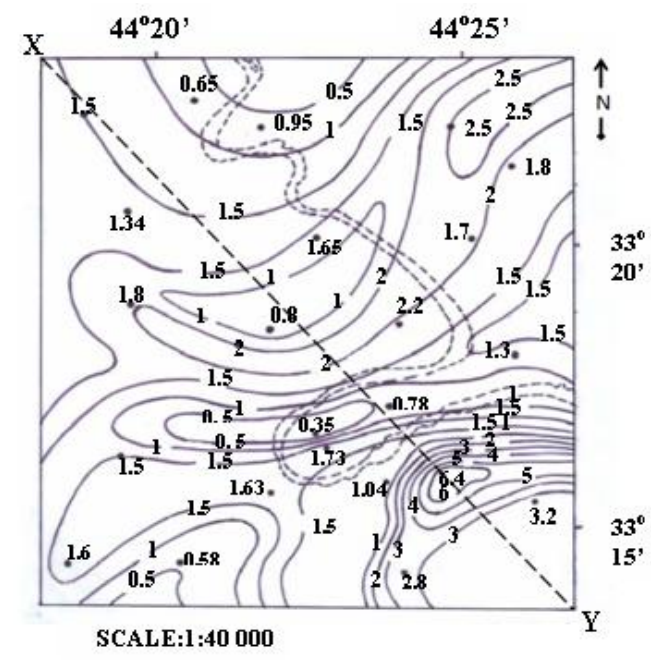

Fig.3: A manual Drawn Equi-EC Contour Map showing Maximum and minimum EC readings.

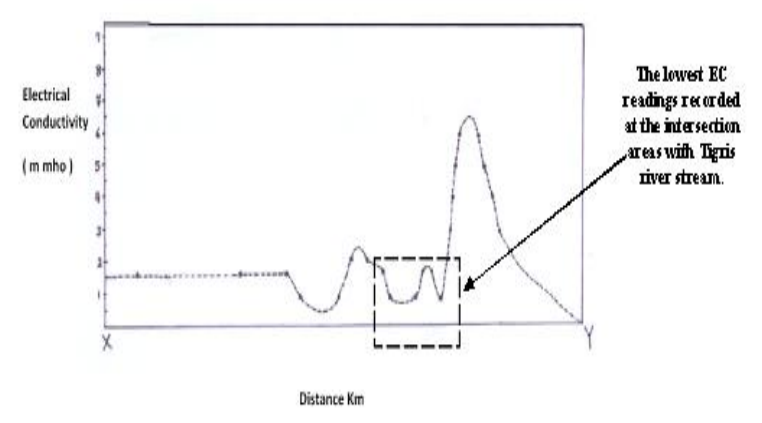

Fig.4: A manual Drawn profile along the traverse $X-Y$ showing EC fluctuation with distance.

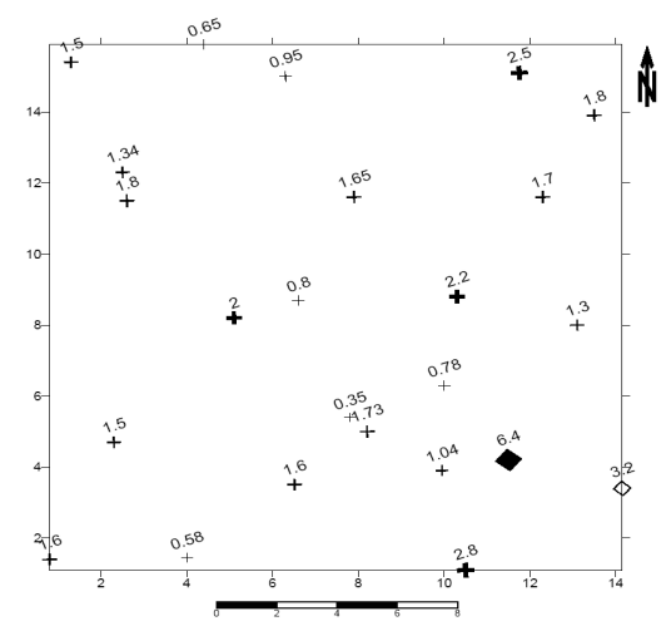

Fig.5: A computer drawn map shows the soil sampling spots with EC values . 


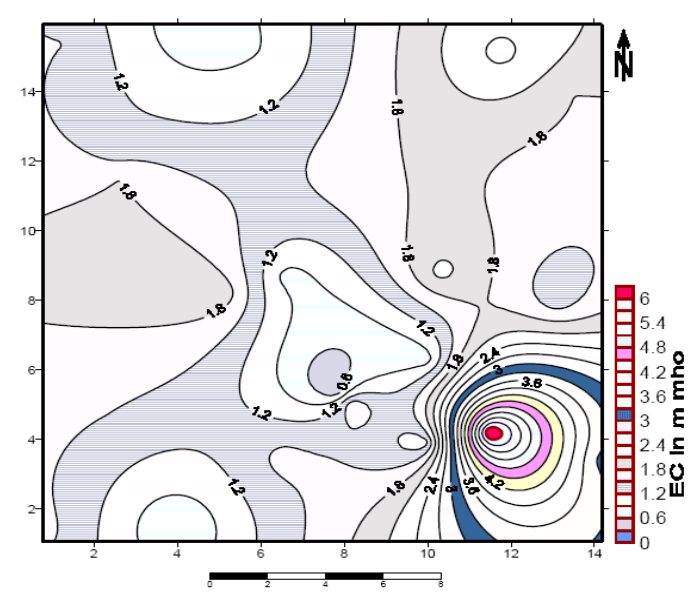

Fig.6: A computer drawn Soil EquiEC Contour Map showing Maximum and minimum EC readings in the study area.

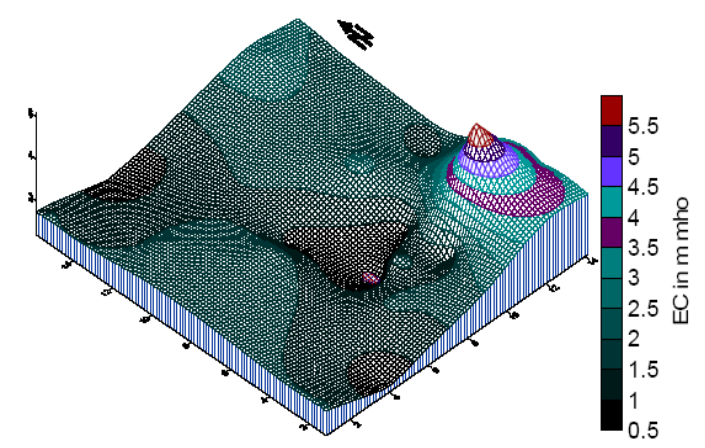

Fig.7: A computer drawn 3-D Soil Equi-EC wire block diagram showing EC values fluctuation in the study area .

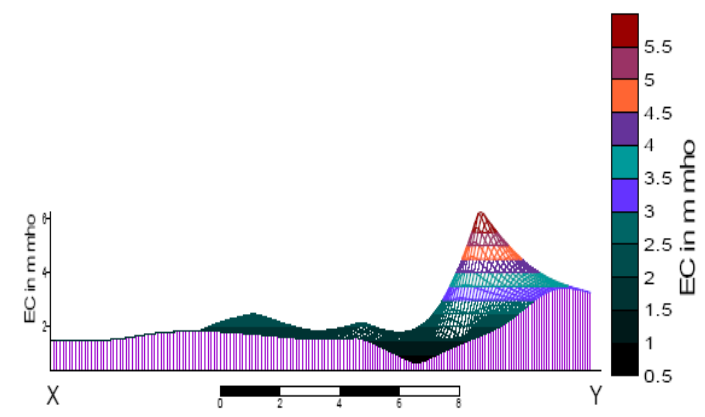

Fig.8: A computer Drawn 3-D profile along the traverse $\mathrm{X}-\mathrm{Y}$ showing EC fluctuation with distance.

\section{Conclusions and recommendations:}

According to the calculated "salt Index" for the area samples and with a comparison with University of Florida
ESTL standard tables we concluded the following:

1- The highest EC or salinity parts of $(6.5 \mathrm{~m}$ mho per $\mathrm{cm}$ ) and salt index of $(51.2 \mathrm{dS} / \mathrm{m})$ at the southern east part of the study area represents a non-plant able area due to high salinity and require to be irrigated with fresh water with EC lower than $(2 \mathrm{~m}$ mho per $\mathrm{cm})$.

2- The low EC or salinity areas like Jadriyah and near Washash of EC ranges $(0.35-1.73 \mathrm{~m}$ mho per $\mathrm{cm})$ and salt index range of $(2.8-13.84$ $\mathrm{dS} / \mathrm{m}$ ) which represent areas of intersection with Tigris river stream in the study area are able to be planted with most crops and tree types and irrigated with fresh low salinity water to preserve it from contamination with salts.

3- The regions located a few kilometers near the river stream of moderate EC readings $(1-2 \mathrm{~m}$ mho per $\mathrm{cm})$ have a salt index range $(8$ $-16 \mathrm{dS} / \mathrm{m})$ are able to be planted with more salinity durable crops and trees and must be irrigated with fresh water of EC lower than (2 m mho per $\mathrm{cm}$ ) .

If salts will affect the selected crops:

1. Provide drainage by ditching, tile or mole drains, etc.

2. Leach the soil with high-quality water. The amount of irrigation water depends upon the depth of the rooting zone (volume of soil), the quality of water, and the method of application to the field. Using water with an EC less than 2.0 deciSiemens per meter is recommended. For sandy Florida soils, 2 to 3 inches of water should provide enough leaching to remove $90 \%$ of the salts from the upper 1.5 to 2 feet of soil.[15,22,23]

The table .2 shows the low, acceptable, optimum, high and very high EC ranges required in general for agricultural benefits. 
Table.2: low, acceptable, optimum, high and very high EC ranges EC required in general for agricultural benefits. [15]

\begin{tabular}{|c|c|c|c|c|c|}
\hline Species Type & Low & Acceptable & Optimum & High & $\begin{array}{c}\text { Very } \\
\text { High }\end{array}$ \\
\hline & \multicolumn{4}{|c|}{------------- dS/m ------------ } & \\
\hline $\begin{array}{c}\text { Woody } \\
\text { Ornamentals }\end{array}$ & $<0.7$ & 0.7 to 1.0 & 1.0 to 1.5 & $\begin{array}{c}1.5 \text { to } \\
3.0\end{array}$ & $>3.0$ \\
\hline $\begin{array}{c}\text { Bedding and } \\
\text { Pot Plants }\end{array}$ & $<0.8$ & 0.8 to 2.0 & 2.0 to 3.5 & $\begin{array}{c}3.5 \text { to } \\
5.0\end{array}$ & $>5.0$ \\
\hline
\end{tabular}

\section{References:}

1- Rhoades, J.D., and Ingvalson, R.D, 1971, Determining salinity in field soils with soil resistance measurements, Soil Sci. Soc. Amer. Proc. 35: 54-60.

2-Austin, R.S., and J.D. Rhoades, 1979, A compact low-cost circuit for reading four electrode salinity sensors, Soil Sci. Soc. Am. J. 43: 808-809.

3- Rhoades, J.D. , Shouse, P.G. , Alves, W.J., Manteghi, N.A. and Lesch, S.M,1990, Determining soil salinity from soil conductivity using different models and estimates ,Soil Sci.Soc.Am.J. 54:46-54.

4- Rhoades, J.D., and J. Van Schilfgaarde, 1976, An electrical conductivity probe for determining soil salinity, Soil Sci. Soc. Am.J. 40:647-650.

5- Dobrin, M.B., 1960, Introduction to geophysical prospecting, McGraw Hill Book Co.,New York USA :364.

6- Crowin, D.L., and J.D. Rhoades, 1984, Measurement of inverted electrical conductivity profiles using electromagnetic induction, Soil Sci. Soc. Am. J. 48:288-291.

7- Liner, C.L., and J.L. Liner, 1997, Application of GPR to a site investigation involving shallow faults, The Leading Edge. November. pp.1647-1651.
8-Halvorson, A.D. and J.D. Rhoades, 1976 , Field mapping soil conductivity to delineate dry land saline seeps with four electrode techniques, Soil Sci. Soc. Am. J. 40:571-574.

9-Pozdnyakova, L.A.,A.I. Pozdnyakov. and L.O. Karpachevsky, 1996, Study hydrology of valley agricultural land scapes with electrical resistance methods Proceeding of XXI Assembly, European Geophysical Society. HS16 the hydrology of small agricultural catchments, The Hague, Netherlands. pp.341-352.

10- Cook, P.G. and Walker G.R., 1992, Depth profiles of electrical conductivity from linear combinations of electromagnetic induction measurements, Soil Sci. Soc. Am. J. 56:1015-1022.

11- Monica Z. Bruckner, 2009 ,Water and Soil Characterization - $\mathrm{pH}$ and Electrical Conductivity Created by, Montana State University, Bozeman, microbial life educational resources, Report July 122009, page 11.

12-Das, B.S., Wraith, J.M. and Inskeep, W.P., 1999, Soil solution electrical conductivity and nitrate concentrations in a crop root zone estimated using time domain reflectometry, Soil Sci. Soc. Am. J. 63:1561-1570.

13- Wiebold W., Palm,K., Sudduth K., Kitchen N., Batchelor B. Kurt Thelen David Clay Don Bullock and German Bollero Ron Schuler ,2009, Measurement and Uses of Soil Electrical Conductivity, the North Central Soybean Research Program and the United Soybean Board in Soil Sci. Soc. Am. J. 62:1253-1261.

14- Amoozegar, F.A., Nielsen, D.R. and Warrick, A.W., 1982, soil solute concentration distributions for spatially varying pore water 
velocities and apparent diffusion coefficients, Soil Sci. Soc. Am. J. 46:3-9.

15- Hanlon, E.A., McNeal, B.L. and Kidder G., 2009, CIR1092Soil and Container Media Electrical Conductivity Interpretations, University of Florida IFAS Extension .7(4):pp.143-167.

16-Corwin, D.L., 2002, measurement of solute concentration using soil water extraction, J. Environ. Qual. 28:471-480.

17-Dane, J.H. and Topp G.C., 2002, Methods of soil analysis ed.No.4, Madison USA, pp.1273.

18-Corwin, D.L. and Lesch, S.M., 2003, Application of electrical conductivity to precision agriculture, Agronomy Journal. 95:.455-471.

19-Rhoades, J.D. and Loveday J., 1990, Salinity in irrigated agriculture, Agronomy Journal. 30:1089-1142.
20- AL-Sayab, A., AL-Ansary, N. , AL-Rawi, D., AL-Jasim J.A. , ALOmary F.S., And AL-Sheikh Z. ,1982, Geology of Iraq (Text Book) ,University of Baghdad \& University of Mosul, (in Arabic), ed.No.1, Iraq, pp. 200.

21-Marshak, S.,2004, Essentials of Geology, Norton \&Company, Inc.1st ed.No.1, USA' pp.536. p131-154.

22- Kidder, G., 1992, Determination of $\mathrm{pH}$, soluble salts, nitrate, phosphorus, potassium, calcium, magnesium, sodium, and chloride in potting media (non-soil mixes) by saturation extraction, In S.J. Donohue (ed.) Southern Coop. Series Bull. (374):28-32.

23- Bresler, E., McNeal, B.L. and Carter, D.L., 1982, Saline and Sodic Soils, Springer-Verlag. Berlin, Germany. pp. 236

\section{عمل خارطة لتساوي قيم التوصيلية الكهربائية و تحديد التلوث بالاملاح لطبقة

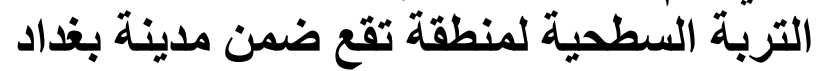
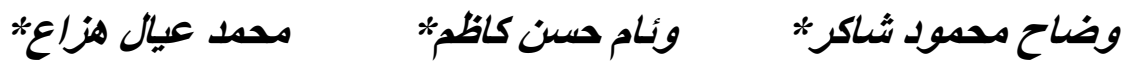 \\ *جامعة بغداد اكلية العلوم للبنات اقسم الفيزياء}

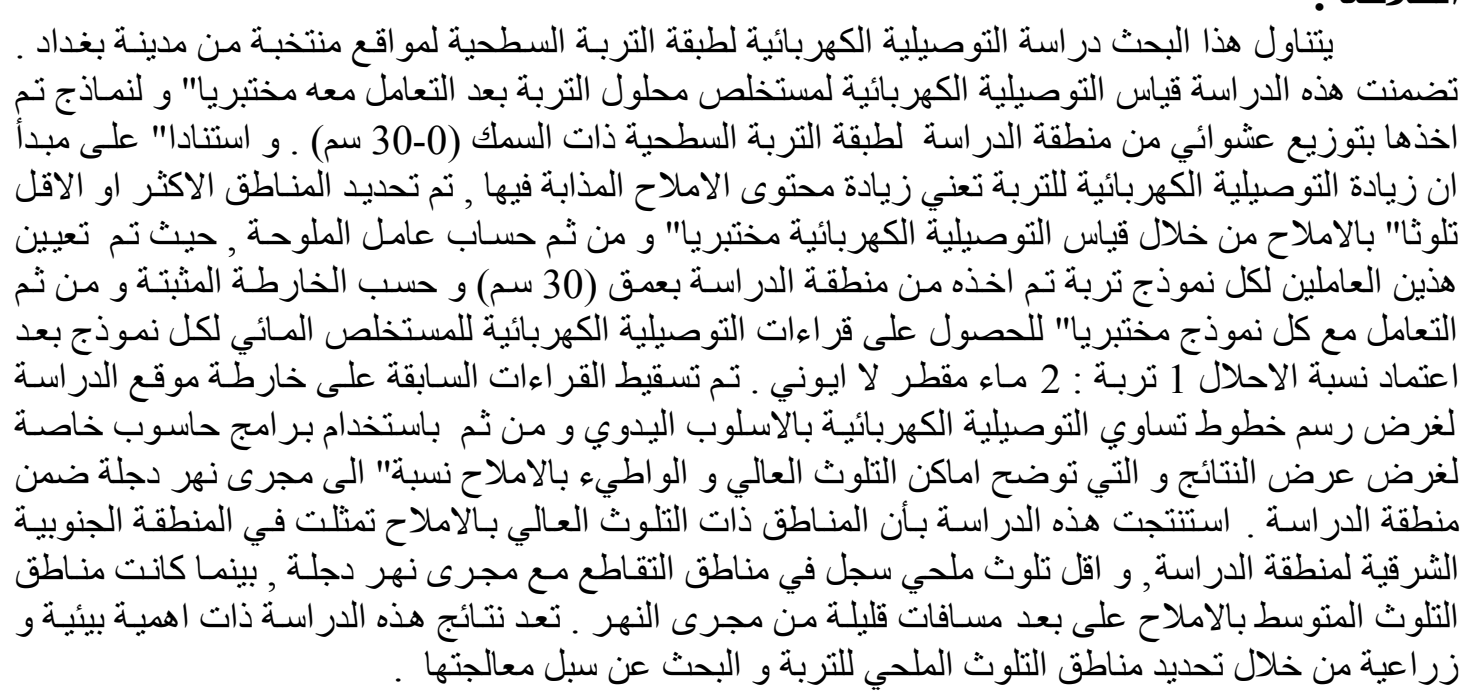

